\title{
The Use of Dupilumab in Atopic Dermatitis During Coronavirus Disease-19 Era - A Review
}

\author{
Laura Pauline Kosasih* \\ Department of Dermatology, Cardiff University, Cardiff, Wales, United Kingdom
}

Edited by: Mirko Spiroski Citation: Kosasih LP. The Use of Dupilumab in Atopic Dermatitis During Coronavirus Disease-19 Era Review. Open Access Maced J Med Sci. 2020 Nov 05;
8(T1):1-9. https://doi.org/10.3889/oamjms.2020.5359 Keywords: Atopic dermatitis; Dupilumab; Biologic treatment; Coronavirus disease-19 pondence: Laura Pauline Kosasih. E-mail:laura.kosasih@gmail.com Received: 08-Aug-2020 Revised: 20-Oct-2020 Copyright: @ 2020 Laura Pauline Kosasih Funding: Publication of this article was financially supported by the Scientific Foundation SPIROSKI, Skopje,
Republic of Macedoni Competing Interests: The authors have declared that no competing interests exis Open Access: This is an open-access article distributed under the terms of the Creative Commons AttributionNonCommercial 4.0 International License (CC BY-NC 4.0)

\begin{abstract}
The global pandemic of coronavirus (CoV) d0isease 2019 (COVID-19), caused by severe acute respiratory syndrome CoV (SARS-CoV 2), has been a challenging event for every individual. It is known that COVID19 may exhibit a vast range of symptoms ranging from mild to severe. Acute respiratory distress syndrome (ARDS) and multiple organ failure are the most common causes of death in COVID-19 cases [3]. Accumulating evidence shows that T-helper type (Th-1) inflammation cascade plays a major role in COVID-19 pathogenesis. It is proposed that aberrant immune reaction, or known as cytokine storm, is one of the main causals of ARDS in COVID-19 case, while dupilumab, the first Food and Drug Administration-approved immunomodulatory treatment for atopic dermatitis, is known for its effectiveness in suppressing the Th-2 inflammation pathway. It is postulated that both types of inflammation can cross-regulate each other. Therefore, some may believe that the regression of Th-2 cascade may upregulate the Th-1 cascade, leading to an exaggerated cytokine storm. This hypothesis leads to the uncertainty of the safety of continuing this modality during the pandemic.
\end{abstract}

\section{Introduction}

Atopic dermatitis (AD) can be deemed as one of the most common non-communicable dermatological ailments. It affects approximately $20 \%$ of children and $2-8 \%$ adults in most nations of the world [1], [2], [3], [4], [5], [6], [7], [8]. An international study shows that the figure has increased two-or three-fold within three decades in the developed countries. Therefore, it is predicted that the number will always accumulate, and this also shows that $A D$ is a global health problem both in developing and developed nations [9].

Both personal and social aspects are greatly influenced by uncontrollable AD. For instance, the social stigma of visible skin efflorescence may affect individual's self-confidence, and debilitating itch might lower one's quality of life [10], [11]. Dupilumab, as the first Food and Drug Administration-approved biologic treatment, has been proven effective and has significantly improved quality of life. Some concerns about the safety of the utilization of dupilumab have been raised during coronavirus (CoV) disease (COVID)-19 pandemic. Some may fear that dupilumab may increase the susceptibility of acquiring COVID-19 or worsen the condition. However, it is also not recommended to discontinue dupilumab because of the chronic nature of $\mathrm{AD}$ and the unknown period of this pandemic [12].
In this article, the literature reviews of both clinical and immunology aspects of dupilumab in AD and COVID-19 have been explored. The aim is to provide the latest reference about dupilumab in $A D$ patients and COVID-19. Thus, it can assist physicians in generating the best clinical judgment in a practice setting.

\section{A Glance of AD}

\section{What is $A D$ ?}

$A D$ is defined as a chronic inflammatory skin disorder, with one of the major hallmarks of extremely pruritic, and it is very common to be found during infancy and childhood period [13]. It is crucial to bear in mind that the diagnosis of $A D$ includes an array of major and minor features. There is no single feature that can represent $A D$ itself nor a diagnostic assessment [14], [15] (Table 1). Many guidelines and suggestions have been published to aid clinicians in establishing the diagnosis. However, it is implied by Tada [16] that mostly adopted guideline for diagnosing both in practice settings and clinical trials is the revised Hanifin and Rajla criteria. The diagnostic can be established when at least three major features and three minor features are noted [17]. 
$A D$ is a very complicated and debilitating condition, and individuals may suffer from both physical and mental issues due to uncontrollable $A D$. Literature shows that $A D$ is significantly affecting all aspects of the quality of life of patients and their families [11], [18], [19] (Figures 1 and 2).

\section{Pathogenesis}

The pathogenesis of $A D$ is subsequently complex and is not fully elucidated until now. Many theories are proposed and postulated; however, it is widely agreed that $A D$ is orchestrated from defective skin integrity, particular genes, and dramatic response of the immune system against exacerbating factors [14], [21], [22].

In general, it is found that $A D$ individuals' skin lacks essential genes that are needed to form a perfect skin barrier. For instance, some individuals may have filaggrin mutation; filaggrin is a gene that encodes essential proteins in building the epithelial barrier and ceramide, a lipid substance that plays an important role in retaining water permeability barrier function [22], [23] The lack of these two major materials leads to excessive trans-epidermal water loss, resulting in $\mathrm{pH}$ alteration and skin dryness. In addition, an antimicrobial peptide called cathelicidin, which is one of the very first layers of immune barrier, is also found to be depleted in most AD patients. [10]. Thus, exacerbating environmental stimuli such as aeroallergens, irritating chemicals, and pathogens are easier to penetrate the skin, initiating inflammation [14], [22], [24].

Th-2 type cells are widely accepted to be associated with both acute and chronic $A D$ course [10], [14], [15]. However, Fujii [25] believes that either in acute and chronic lesion, there might be a switch from Th2 to Th1 activity.

In the acute event, interleukin (IL)-4, IL-5, IL-13, IL-25, and IL-33 levels increase [15]. Especially, in the early lesion of $A D$, it is shown that IL-4 and IL-13 dominate the inflammatory cascade [14], [15]. Meanwhile, in chronic AD, IL-31 has recently been discovered to be overly expressed and linked to the severity of the course.

On the other hand, it is also found that IL-4, IL-13, and IL-33 might downregulate the filaggrin, and thus, it is like a loophole of the immune system and defective skin barrier cascades [26].

\section{Management}

\section{Overview}

In general, many findings agree that the aim of the treatment of $A D$ must be focused on inflammation cessation by repairing the skin barrier and reducing the itch. The importance of education about the nature of the ailment, skin hydration, pharmacological regime, identification, and elimination of flare causal factors is often highlighted in virtually all guidelines [10], [14], [27]. Therefore, holistic and multi-faceted approaches are needed to manage this ailment. [8], [10], [28]. The Japanese guideline for $A D$ believes that the management of $A D$ must be based on three fundamental aspects. First is the investigation and countermeasures of the causal and exacerbating elements. Second is the repairment if the skin defect (skincare). Last is pharmacotherapy [28]. Similarly, the European Consensus Guidelines' treatment option is quite similar to most guidelines and literature, aside from its agreement to divide the management into four phases: Baseline, mild, moderate, and severe [8]. The phases depend on the SCORing AD (SCORAD) (Appendix 1). SCORAD is one of the tools that can be used in assessing the extent and severity of AD. Less than SCORAD 25 is defined as mild, $25-50$ as moderate, and more than 50 as severe. It is also suggested that in each phase, adding additional medication and antiseptic or antibiotic may be beneficial in treating superinfection.

\section{A Brief Review of Dupilumab}

Dupilumab is a human analogue monoclonal antibody that blocks IL-4 and IL-13 pathways by binding a shared $\alpha$-subunit of IL-4 and IL-13, both of which are the major cytokines for Th- 2 inflammation in $A D$ [4], [29], [30].

Some experimental research demonstrated that early treatment with IL-4 and IL-3 blocking agents will dampen the responses to IFN and IL -17 . In brief, when the early lesion of $A D$ is exposed to IL-4 and IL-13, long-lasting persistent effects are doable [31]. Therefore, not only will dupilumab decrease the flare but it may also prevent the course of recalcitrant $A D$ in the future. Dupilumab can be used either as monotherapy or combination therapy. Studies of dupilumab in 4 weeks and 12 weeks as monotherapy and as a combination with topical glucocorticoid in moderate-severe AD show significant improvement [5]. Not only were skin lesions improved but the severity of itch also rapidly decreased, allowing individuals to have a better quality of life. These results were also supported by a separate study, where Eczema Area and Severity Index score and peak pruritus Numerical Rating Score were reported to be significantly improved by the end of week $16^{\text {th }}$ [32]. In terms of adverse effects, both placebo and intervention groups were almost equal [5], [32]. However, in a two phase 3 trial, it is also observed that nasopharyngitis was the second most common adverse effect after infection and infestation in the dupilumab groups [32]. A similar result is also discovered in a study of dupilumab and asthmatic patients [33]. 


\section{COVID-19}

\section{What is COVID-19?}

\section{History}

In December 2019, several pneumonia-like cases with unknown etiology were reported in Wuhan, China. This disease has started with suggestive symptoms of progressive respiratory infection, with some patients developing acute respiratory distress syndrome (ARDS), acute respiratory failure, and other life-threatening complications [34]. A novel beta-CoV was discovered later in January 2020 to be the culprit. International Virus Classification Commission named the virus as Severe Acute Respiratory Syndrome-CoV 2 (SARS-CoV 2), while the World Health Organization (WHO) officially named the disease as COVID-19 in the next month [1], [35]. In March 2020, the WHO asserted that this disease is a global emergency, affecting every aspect of life, and thus, declared COVID-19 as a pandemic [36] (Figure 3).

\section{Incubation and Clinical Characteristic}

Data show that symptoms of COVID-19 usually appear after an incubation period of 5.1-12 days [37]. Fever, dry cough, and fatigue are the most common symptoms. However, other symptoms such as headache, hemoptysis, and gastrointestinal symptoms such as diarrhea and vomiting are likely to be exhibited as well. In addition, dyspnea is found to be developed in more than half of the patients [1], [38], [39]. A recent study also discovered that olfactory dysfunction such as anosmia and hyposmia was found prominently in COVID-19 patients [40]. However, COVID-19 can still yield in a person without showing any symptom, which makes this ailment easily transmitted.

\section{Route of Transmission}

Human-to-human transmission is feasible due to respiratory fomites or droplets. It is also suggested that direct and non-direct contacts through mucous membrane of eyes, nose, mouth, and skin are another potential routes of transmission [39], [41]. However, a recent study discovered that aerosol transmission is highly plausible through smaller droplets or droplet nuclei. Therefore, proper inter-personal distancing and usage of mask are very essential to control the spread of infection [42], [43]. Due to a recent study that shows COVID-19 cases with enteric symptoms, it is also suggested that the digestive tract might be another possible route of transmission [44].

An article also suggests that percutaneous transmission is possible due to the high expression of Angiotensin-Converting Enzyme-2 (ACE2) in the skin tissue cells [45]. ACE-2 is known to facilitate the entry of the virus (further explanation will be explained in the next chapter). However, a thorough study is still needed to elucidate this hypothesis.

\section{Pathogenesis}

\section{Virus structure}

CoVs are enveloped with single-stranded, positive-strand RNA genome (26-32kb in weight) which comes from Coronaviridae family. There are four genera of CoVs; $\alpha, \beta, \gamma, \delta$, and COVID-19 belongs to the beta-CoV genus. Within beta genus itself, there are four lineages $(A, B, C$, and $D)$ [3], [46].

The appearance of the virus is a rough, spherical and has prominent club-shaped elongations which contain its spike protein. This novel CoV has shown $88 \%$ similarity to bat-related SARS-like CoVs' sequence (bat-SL-CoVZC45 and bat-SLCoVZXC21), and approximately $50 \%$ identical to Middle East Respiratory Syndrome CoVs' sequence. Due to its similar structure, the pathogenesis of SARS-CoV 2 can be postulated. However, the complete pathogenesis of COVID-19 has not been fully elucidated [47].

Table 1: Major and minor features. Adapted from Goldsmith et al. and Correale et al. [14], [20]

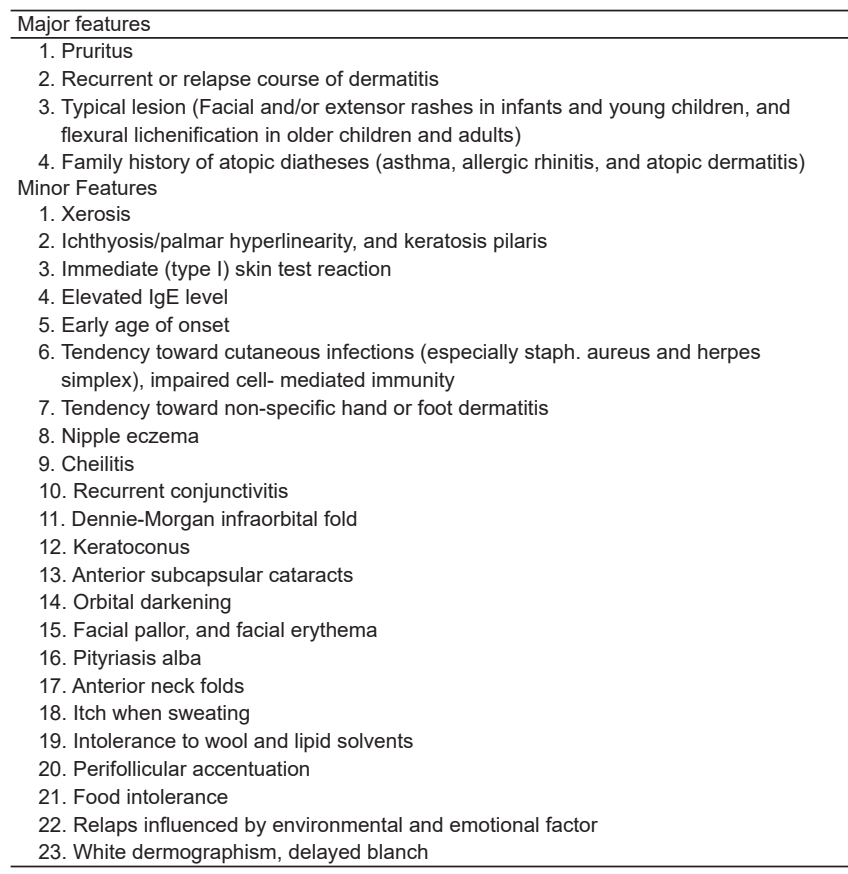




\section{(a) Treatment recommendation for atopic eczema: adult \\ - For every phase, additional therapeutic options should be considered \\ - Add antiseptics / antibiotics in cases of superinfection \\ - Consider compliance and diagnosis, if therapy has insufficient effect \\ - Refer to guideline text for restrictions, especially for treatment marked with ' \\ - Licensed indication are marked with ${ }^{2}$, off-label treatment options are marked with ${ }^{3}$}

\begin{tabular}{|c|c|c|}
\hline & $\begin{array}{l}\text { SEVERE: } \\
\text { SCORAD > } 50 / \text { or } \\
\text { persistent eczema }\end{array}$ & $\begin{array}{l}\text { Hospitalization; systemic immunosuppression: } \\
\text { cyclosporine } \mathrm{A}^{2} \text {, short course of oral } \\
\text { glucocorticosteroids } \\
\text { azathioprin }{ }^{3}, \text { dupilumab }^{1,2} \text {, methotrexate }{ }^{3} \text {, } \\
\text { alitretinoin }{ }^{1,3}\end{array}$ \\
\hline & $\begin{array}{l}\text { MODERATE: } \\
\text { SCORAD 25-50 / or } \\
\text { recurrent eczema }\end{array}$ & $\begin{array}{l}\text { Proactive therapy with topical tacrolimus }{ }^{2} \text { or class } \\
\text { II or class III topical glucocorticosteroids }{ }^{3} \text {, wet wrap } \\
\text { therapy, UV therapy (UVB } 311 \mathrm{~nm} \text {, medium dose UVA1), } \\
\text { psychosomatic counseling, climate therapy }\end{array}$ \\
\hline $\begin{array}{l}\text { MILD: } \\
\text { SCOF } \\
\text { transi }\end{array}$ & $\begin{array}{l}<25 / \text { or } \\
\text { t eczema }\end{array}$ & $\begin{array}{l}\text { Reactive therapy with topical glucocorticosteroids class } \\
\|^{2} \text { or depending on local cofactors: topical calcineurin } \\
\text { inhibitors }^{2} \text {, antiseptics incl. silver }{ }^{2} \text {, silver coated textiles ' }\end{array}$ \\
\hline $\begin{array}{l}\text { BASELINE: } \\
\text { Basic therapy }\end{array}$ & & $\begin{array}{l}\text { Educational programmes, emollients, bath oils, } \\
\text { avoidance of clinically relevant allergens (encasings, if } \\
\text { diagnosed by allergy tests) }\end{array}$ \\
\hline
\end{tabular}

Figure 1: Management scheme of AD in adults. Adapted from Wollenberg A, Barbarot S, Bieber T, Christen-Zaech S, Deleuran M, FinkWagner A, et al. Consensus-based European guidelines for treatment of atopic eczema (atopic dermatitis) in adults and children: part I. $J$ Eur Acad Dermatol Venereol. 2018 May;32(5):657-82

\section{Host Entrance and Immune Response}

SARS-CoV 2 can enter the host cells by direct membrane fusion. First, the envelope spike glycoprotein will bind to the host cellular receptor, facilitated by ACE2 [48]. After entering the cell, the virus RNA genome will be released to the cytoplasm and then commenced to the replication phase [49].

Subsequently, after the virus has successfully hijacked the cells, its antigen will be presented to the antigen presentation cells. Antigen presentation will evoke host immune response which is both humoral and cellular immunity. T cells and B cells play a major role as the immune mediators in this event [35].

Since COVID-19 is caused by a virus, similar to any viral infection, the innate immune pathway is the first line of defense. However, a further aberrant and disarrayed immune response might damage the immune systems, leading to fatality [3], [50]. This event is often known as a cytokine storm. Several studies report that ARDS is the main cause of mortality of COVID-19 patients, and ARDS is one of the results of the cytokine storm [3], [51], [52]. This dramatic cytokines response makes COVID-19 difficult to manage and threaten lives.
T-helper type 1 (Th-1) cascade plays an essential role in COVID-19 infection. It is observed that cytokines that generate Th-1 pathway such as IL-1B, IFN- $\gamma$, IP-10, and monocyte chemoattractant protein 1 rise [51]. This hypothesis is also supported by several studies and reports discovering highly expressed Th-1 related cytokines in many COVID-19 patients. For instance, a study by Huang et al. revealed that levels of IL-7, IL-8, IL-9, IL-10, fibroblast growth factor, granulocyte-colony stimulating factor, granulocytemacrophage colony-stimulating factor, MIP-1A,MIP1-B, platelet-derived growth factor, tumor necrosis factor (TNF) $\alpha$, and VEGF surge in both ICU and non-ICU required COVID-19 patients compared to healthy individuals [51].

An analyzing case study in China also saw a high expression of IL-10, IL-6, and TNF- $\alpha$ in severe cases compared to moderate cases [53]. An identical result is also found in a study of assessment of laboratory data reporting that IL-6 level significantly rises in severe cases compared to mild cases [54]. A multicenter study also supports previous data, in which it is observed that IL- 6 was found higher in mortality cases than successful cases [55]. 
(b) Treatment recommendation for atopic eczema: children

- For every phase, additional therapeutic options should be considered

- Add antiseptics / antibiotics in cases of superinfection

- Consider compliance and diagnosis, if therapy has insufficient effect

- Refer to guideline text for restrictions, especially for treatment marked with '

- Licensed indication are marked with ${ }^{2}$, off-label treatment options are marked with $^{3}$

\begin{tabular}{|ll}
\hline SEVERE: & Hospitalization, systemic immunosuppression: \\
SCORAD $>\mathbf{5 0} /$ or & cyclosporine $\mathrm{A}^{3}$, methotrexate ${ }^{3}$, azathioprin ${ }^{3}$, \\
persistent eczema & mycophenolate mofetil 1,3
\end{tabular}

MODERATE:

SCORAD 25-50/ or recurrent eczema
Proactive therapy with topical tacrolimus ${ }^{2}$ or class II or III topical glucocorticosteroids ${ }^{3}$, wet wrap therapy, UV therapy (UVB $311 \mathrm{~nm}$ ) ', psychosomatic counseling, climate therapy

\section{MILD: \\ SCORAD $<25$ / or transient eczema}

Reactive therapy with topical glucocorticosteroids class $\|^{2}$ or depending on local cofactors: topical calcineurin inhibitors ${ }^{2}$, antiseptics incl. silver, silver coated textiles

\section{BASELINE: Basic therapy}

Educational programmes, emollients, bath oils, avoidance of clinically relevant allergens (encasings, if diagnosed by allergy tests)

Figure 2: Management scheme of AD in children. Adapted from Wollenberg A, Barbarot S, Bieber T, Christen-Zaech S, Deleuran M, FinkWagner A, et al. Consensus-based European guidelines for treatment of atopic eczema (atopic dermatitis) in adults and children: part I. J Eur Acad Dermatol Venereol. 2018 May;32(5):657-82

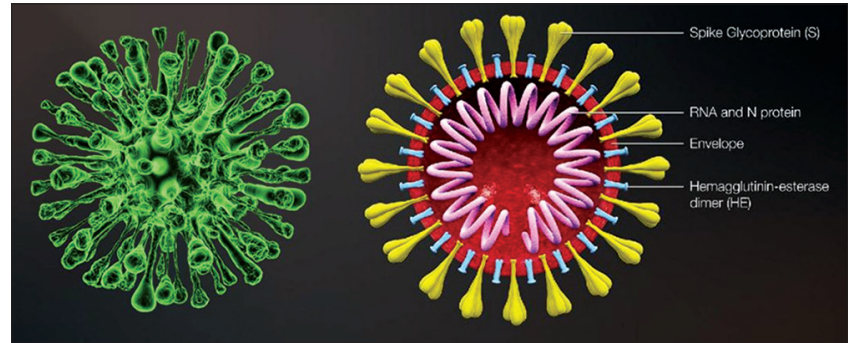

Figure 3: Structure of SARS-CoV 2. Adapted from https:// microbeonline.com/sars-cov-2-properties-transmission

\section{Discussion}

\section{Dupilumab during COVID-19 era}

It is understandable that COVID-19 alters the nature of $A D$ management with dupilumab. Some $A D$ patients may abruptly cease the treatment or refuse to take it routinely. Some cases may be caused due to the difficulty for accessing dermatology practices that are closed during lockdown or the fear of contracting COVID-19 from clinic visit [56]. Others may have concerns about the effect of dupilumab therapy and susceptibility of acquiring COVID-19.
Even though there are some letters of statement about the usage of immunomodulators usage in dermatology cases during COVID-19 [57], [58], more sources that provide information about the safety of biologic treatment during the COVID-19 outbreak are needed [59]. Even though dupilumab is not an immunosuppressant nor steroid that might reduce the immune systems, it is postulated that immunomodulators may affect the balance of the immune system [6]. The Th1/Th2 immune balance has been studied for decades. However, it is ultimately complex and has not been fully elucidated until now. It is believed that the integration of the immune system is achieved by cell-to-cell communication, facilitated by cytokines. Therefore, it can modulate those cells to become more active (upregulate) or less active (downregulate) [7]. It is hypothesized that suppression of Th-2 polarized cytokines may upregulate the Th- 1 cascade activity. For instance, IL-10 is known to release from the Th-2 pathway, and it can downregulate Th-1 production [6]. This hypothesis is also supported by a study in autoimmune disease, stating that Th-1 and Th-2 inflammations work to antagonize each other. This may be achieved either by inhibiting the production of the other cell type or by hindering each other effector function. For instance, abundant expression of IL-3 or IL-6 may block the generation of Th-1 cells from naive T cells [60]. 
In other words, it is plausible that the production of Th-1 polarized cytokines is upregulated due to the decreased Th-2 activity, resulting from the lower expression of IL-4 and IL-13, blocked by dupilumab. This may worsen or increase the risk of aberrant cytokine storm in COVID-19 patients. However, a study disputes that dupilumab affects Th-1 activity. It is shown that no elevation of Th-1/IFN-grelated gene expression was observed in $A D$ patients with dupilumab [61]. Moreover, a hypothesis is also proposed that dupilumab might give $A D$ patients more protection from COVID-19 infection. It is known that expression of IL-6, one of the infamous cytokines that play role in cytokine storm, is depended on endogenous production of IL-4, which obviously decreases in patient on dupilumab. This mechanism gives the possibility of protective effect of dupilumab in the nature of COVID-19 [62].

Many have proposed that the concept of Th-1/ Th-2 immune balance is very complex and not only influenced by the cytokines profile but also by antigen presentation, immunogenic and non-immunogenic cells, genetic, hormones, oxidative stress, and environment [6], [60], [63], [64]. Thus, further research is needed to elucidate this matter.

\section{Limitations and Recommendation}

One of the limitations of this article is the sparse data of COVID-19 due to its novelty. Another limitation includes the strength of the data of dupilumab, since the most common available sources are randomizedcontrolled trials. In addition, most of the sources of the immunology cascades are theoretical data, and there is still little clinical evidence that can support the theory. It is recommended that physicians strictly follow-up patients with dupilumab and record their development during this pandemic.

The use of biologic modality in dermatological conditions during the pandemic may be challenging. Any decision either discontinuation or continuation of the modality may be obtained based on the evaluation of patient's profile and the risk of contracting COVID-19, particularly in high caseload zone. The continuation of biologic treatment is highly suggested with careful monitoring of any undesirable or uncommon side effects. Finally, further studies are required urgently to elucidate this matter.

\section{References}

1. Rothan HA, Byrareddy SN. The epidemiology and pathogenesis of coronavirus disease (COVID-19) outbreak. J Autoimmun. 2020;109:102433. https://doi.org/10.1016/j.jaut.2020.102433

\section{PMid:32113704}

2. Kakodkar P, Kaka N, Baig M. A comprehensive literature review on the clinical presentation, and management of the pandemic coronavirus disease 2019 (COVID-19). Cureus. 2020;12(4):e7560. https://doi.org/10.7759/cureus.7560 PMid:32269893

3. Ye Q, Wang B, Mao J. The pathogenesis and treatment of the "Cytokine Storm" in COVID-19. J Infect. 2020;80(6):607-13. PMid:32283152

4. Wang FP, Tang XJ, Wei CQ, Xu LR, Mao H, Luo FM. Dupilumab treatment in moderate-to-severe atopic dermatitis: A systematic review and meta-analysis. J Dermatol Sci. 2018;90(2):190-8. https://doi.org/10.1016/j.jdermsci.2018.01.016 PMid:29472119

5. Beck LA, Thaçi D, Hamilton JD, Graham NM, Bieber T, Rocklin R, et al. Dupilumab treatment in adults with moderateto-severe atopic dermatitis. N Engl J Med. 2014;371(2):130-9. https://doi.org/10.1056/nejmoa1314768

6. Kidd P. Th1/Th2 balance: The hypothesis, its limitations and implications for health and disease. Altern Med Rev. 2003;8(3):223-46

PMid:12946237

7. Balkwill FR. The Cytokine Network. Oxford: Oxford University Press; 2000. Available from: https://www.books.google.com.vc/ books?id=8tdCmwEACAAJ. [Last accessed on 2020 Aug 07].

8. Wollenberg A, Barbarot $\mathrm{S}$, Bieber $\mathrm{T}$, Christen-Zaech $\mathrm{S}$, Deleuran M, Fink-Wagner A, et al. Consensus-based European guidelines for treatment of atopic eczema (atopic dermatitis) in adults and children: Part I. J Eur Acad Dermatol Venereol. 2018;32(5):657-82. https://doi.org/10.1111/jdv.14891 PMid:29676534

9. Asher MI, Montefort S, Björkstén B, Lai CK, Strachan DP, Weiland SK, et al. Worldwide time trends in the prevalence of symptoms of asthma, allergic rhinoconjunctivitis, and eczema in childhood: ISAAC Phases One and Three repeat multicountry cross-sectional surveys. Lancet (London, England). 2006;368(9537):733-43. https://doi.org/10.1016/ s0140-6736(06)69283-0 PMid:16935684

10. Kapur S, Watson W, Carr S. Atopic dermatitis. Allergy Asthma Clin Immunol. 2018;14(2):52. https://doi.org/10.1186/ s13223-018-0281-6 PMid:30275844

11. Koszorú K, Borza J, Gulácsi L, Sárdy M. Quality of life in patients with atopic dermatitis. Cutis. 2019;104(3):174-7.

PMid:31675393

12. Price KN, Frew JW, Hsiao JL, Shi VY. COVID-19 and immunomodulator/immunosuppressant use in dermatology. J Am Acad Dermatol. 2020;82(5):e173-5.

PMid:32224277

13. Krakowski AC, Eichenfield LF, Dohil MA. Management of atopic dermatitis in the pediatric population. Pediatrics. 2008;122(4):812-24. https://doi.org/10.1542/peds.2007-2232 PMid: 18829806

14. Goldsmith LA, Katz SI, Gilchrest BA, Paller AS, Leffell DJ, Wolff K. Fitzpatrick's Dermatology in General Medicine. $8^{\text {th }}$ ed. New York: McGraw-Hill; 2012. p. 165-7. https://doi. org/10.1111/j.1524-4725.2008.34211.x

15. Boguniewicz M, Fonacier L, Leung DY. Atopic and Contact Dermatitis: Clinical Immunology. $5^{\text {th }}$ ed. Netherland: Elsevier Ltd.; 2006. p. 611-24.

16. Tada J. Diagnostic standard for atopic dermatitis. JMAJ. 2002;45(4511):460-5I.

17. Hanifin JM, Rajla G. Diagnostic features of AD. Acta Dermatovener (Stockholm). 1980;92:44-7. 
18. McKenna SP, Doward LC. Quality of life of children with atopic dermatitis and their families. Curr Opin Allergy Clin Immunol. 2008;8(3):228-31. PMid:18560297

19. Lifschitz $C$. The impact of atopic dermatitis on quality of life. Ann Nutr Metab. 2015;66(Suppl 1):34-40

PMid:25925339

20. Correale CE, Walker C, Murphy L, Craig TJ. Atopic dermatitis: A review of diagnosis and treatment. Am Fam Physician. 1999;60(4):1191-8, 1209-10.

PMid:10507748

21. Manousaki D, Paternoster L, Standl M, Moffatt MF, Farrall M, Bouzigon $\mathrm{E}$, et al. Vitamin $\mathrm{D}$ levels and susceptibility to asthma, elevated immunoglobulin E levels, and atopic dermatitis: A mendelian randomization study. PLoS Med. 2017;14(5):e1002294. https://doi.org/10.1371/journal. pmed.1002294

PMid:28486474

22. Martin MJ, Estravís M, García-Sánchez A, Dávila I, IsidoroGarcía M, Sanz C. Genetics and epigenetics of atopic dermatitis: An updated systematic review. Genes (Basel). 2020;11(4):442. https://doi.org/10.3390/genes11040442 PMid:32325630

23. Candi E, Schmidt R, Melino G. The cornified envelope: A model of cell death in the skin. Nat Rev Mol Cell Biol. 2005;6(4):32840. https://doi.org/10.1038/nrm1619

PMid:15803139

24. Maliyar K, Sibbald C, Pope E, Gary Sibbald R. Diagnosis and management of atopic dermatitis: A review. Adv Skin Wound Care. 2018;31(12):538-50. https://doi.org/10.1097/01. asw.0000547414.38888.8d

PMid:30475283

25. Fujii M. Current understanding of pathophysiological mechanisms of atopic dermatitis: Interactions among skin barrier dysfunction, immune abnormalities and pruritus. Biol Pharm Bull. 2020;43(1):12-9. https://doi.org/10.1248/bpb. b19-00088

PMid:31902917

26. Seltmann J, Roesner LM, von Hesler FW, Wittmann M, Werfel T. IL-33 impacts on the skin barrier by downregulating the expression of filaggrin. J Allergy Clin Immunol. 2015;135(6):1659-61.e4. https://doi.org/10.1016/j.jaci.2015.01.048 PMid:25863977

27. Mayba JN, Gooderham MJ. Review of atopic dermatitis and topical therapies. J Cutan Med Surg. 2017;21(3):227-36. https:// doi.org/10.1177/1203475416685077

PMid:28300440

28. Katayama I, Aihara M, Ohya Y, Saeki H, Shimojo N, Shoji S, et al. Japanese guidelines for atopic dermatitis 2017. Allergol Int. 2017;66(2):230-47. https://doi.org/10.1016/j.alit.2016.12.003 PMid:28209325

29. Mollanazar NK, Smith PK, Yosipovitch G. Mediators of chronic pruritus in atopic dermatitis: Getting the itch out? Clin Rev Allergy Immunol. 2016;51(3):263-92. https://doi.org/10.1007/ s12016-015-8488-5

30. Leung D, Boguniewicz M. Atopic dermatitis and allergic contact dermatitis. In: Middleton's Allergy Essentials. amsterdam: Elsevier Inc.; 2017. p. 265-300. https://doi.org/10.1016/ b978-0-323-37579-5.00011-8

31. Rich RR, Fleisher TA, Shearer WT, Schroeder HW Jr., Frew AJ. Clinical Immunology: Principles and Practice. $5^{\text {th }}$ ed. Amsterdam, Netherlands: Elsevier; 2019.

32. Thaçi D, Simpson E, Deleuran M, Kataoka Y, Chen Z, Gadkari A, et al. Efficacy and safety of dupilumab monotherapy in adults with moderate-to-severe atopic dermatitis: A pooled analysis of two phase 3 randomized trials (LIBERTY AD SOLO 1 and LIBERTY AD SOLO 2). J Dermatol Sci. 2019;94(2):266-75. https://doi.org/10.1016/j.jdermsci.2019.02.002

PMid:31109652

33. Wenzel S, Ford L, Pearlman D, Spector S, Sher L, Skobieranda $\mathrm{F}$, et al. Dupilumab in persistent asthma with elevated eosinophil levels. N Engl J Med. 2013;368(26):2455-66. https://doi. org/10.1056/nejmoa1304048

PMid:23688323

34. Chen N, Zhou M, Dong X, Qu J, Gong F, Han Y, et al. Epidemiological and clinical characteristics of 99 cases of 2019 novel coronavirus pneumonia in Wuhan, China: A descriptive study. Lancet. 2020;395(10223):507-13. https://doi.org/10.1016/ s0140-6736(20)30211-7

PMid:32007143

35. Li X, Geng M, Peng Y, Meng L, Lu S. Molecular immune pathogenesis and diagnosis of COVID-19. J Pharm Anal. 2020;10(2):102-8.

PMid:32282863

36. World Health Organization. Timeline of WHO's response to COVID-19. World Health Organ. 2020;1:1-27.

37. Lauer SA, Grantz KH, Bi Q, Jones FK, Zheng Q, Meredith HR, et al. The incubation period of coronavirus disease 2019 (CoVID19) from publicly reported confirmed cases: Estimation and application. Ann Intern Med. 2020;172(9):577-82. https://doi. org $/ 10.7326 / \mathrm{m} 20-0504$

PMid:32150748

38. Wang D, Hu B, Hu C, Zhu F, Liu X, Zhang J, et al. Clinical characteristics of 138 hospitalized patients with 2019 novel coronavirus infected pneumonia in Wuhan, China. JAMA. 2020;323(11):1061-9. https://doi.org/10.1001/jama.2020.1585 PMid:32031570

39. Guo YR, Cao QD, Hong ZS, Tan YY, Chen SD, Jin HJ, et al. The origin, transmission and clinical therapies on coronavirus disease 2019 (COVID-19) outbreak an update on the status. Mil Med Res. 2020;7(1):11. https://doi.org/10.1186/s40779-020-00240-0

40. Meng X, Deng Y, Dai Z, Meng Z. COVID-19 and anosmia: A review based on up-to-date knowledge. Am J Otolaryngol. 2020;41(5):102581. https://doi.org/10.1016/j.amjoto.2020.102581 PMid:32563019

41. World Health Organization. Report of the WHO-China Joint Mission on Coronavirus Disease 2019 (COVID-19). WHOChina Jt Mission Coronavirus Disease. Geneva: World Health Organization; 2019. Available from: https://www.who.int/docs/ default-source/coronaviruse/who-china-joint-mission-on-covid19-final-report.pdf. [Last accessed on 2020 Aug 03]. https://doi. org/10.3410/f.737509210.793572110

42. Morawska L, Tang JW, Bahnfleth W, Bluyssen PM, Boerstra A, Buonanno G, et al. How can airborne transmission of COVID19 indoors be minimised? Environ Int. 2020;142:105832. https:// doi.org/10.1016/j.envint.2020.105832

PMid:32521345

43. Setti L, Passarini F, De Gennaro G, Barbieri P, Perrone MG, Borelli $\mathrm{M}$, et al. Airborne transmission route of covid-19: Why 2 meters/6 feet of inter-personal distance could not be enough. Int J Environ Res Public Health. 2020;17(8):2932. https://doi. org/10.3390/ijerph17082932

PMid:32340347

44. Zhang $\mathrm{H}$, Kang Z, Gong $\mathrm{H}, \mathrm{Xu} \mathrm{D}$, Wang J, Li Z, et al. The Digestive System is a Potential Route of 2019-nCov Infection: A Bioinformatics Analysis Based on Single-Cell Transcriptomes. bioRxiv; 2020. Available from: http://www.biorxiv.org/content/ear ly/2020/01/31/2020.01.30.927806.abstract. [Last accessed on 2020 Aug 03]. https://doi.org/10.1101/2020.01.30.927806

45. Xue X, Mi Z, Wang Z, Pang Z, Liu H, Zhang F. High expression of ACE2 on keratinocytes reveals skin as a potential target 
for SARS-CoV-2. J Invest Dermatol. 2020;1:1-5. https://doi. org/10.1016/j.jid.2020.05.087

46. Su S, Wong G, Shi W, Liu J, Lai AC, Zhou J, et al. Epidemiology, genetic recombination, and pathogenesis of coronaviruses. Trends Microbiol. 2016;24(6):490-502. PMid:27012512

47. Lu R, Zhao X, Li J, Niu P, Yang B, Wu H, et al. Genomic characterisation and epidemiology of 2019 novel coronavirus: Implications for virus origins and receptor binding. Lancet. 2020;395(10224):565-74.

PMid:32007145

48. Tanonaka K, Marunouchi T. Angiotensin-converting enzyme 2. Folia Pharmacol Jpn. 2016;147(2):120-1. https://doi. org/10.1254/fpj. 147.120

49. Perlman S, Netland J. Coronaviruses post-SARS: Update on replication and pathogenesis. Nat Rev Microbiol. 2009;7(6):43950. https://doi.org/10.1038/nrmicro2147 PMid: 19430490

50. Channappanavar R, Fehr AR, Vijay R, Mack M, Zhao J, Meyerholz DK, et al. Dysregulated Type I interferon and inflammatory monocyte-macrophage responses cause lethal pneumonia in SARS-CoV-infected mice. Cell Host Microbe. 2016;19(2):181-93. https://doi.org/10.1016/j.chom.2016.01.007 PMid:26867177

51. Huang C, Wang Y, Li X, Ren L, Zhao J, Hu Y, et al. Clinical features of patients infected with 2019 novel coronavirus in Wuhan, China. Lancet. 2020;395(10223):497-506. https://doi. org/10.1016/s0140-6736(20)30183-5

52. Li H, Liu SM, Yu XH, Tang SL, Tang CK. Coronavirus disease 2019 (COVID-19): Current status and future perspectives. Int J Antimicrob Agents. 2020;55(5):105951. https://doi. org/10.1016/j.jjantimicag.2020.105951 PMid:32234466

53. Chen G, Wu D, Guo W, Cao Y, Huang D, Wang H, et al. Clinical and immunological features of severe and moderate coronavirus disease 2019. J Clin Invest. 2020;130(5):2620-9 PMid:32217835

54. Gao Y, Li T, Han M, Li X, Wu D, Xu Y, et al. Diagnostic utility of clinical laboratory data determinations for patients with the severe COVID-19. J Med Virol. 2020;92(7):791-6. https://doi. org/10.1002/jmv.25770

PMid:32181911

55. Ruan Q, Yang K, Wang W, Jiang L, Song J. Clinical predictors of mortality due to COVID-19 based on an analysis of data of 150 patients from Wuhan, China. Intensive Care Med. 2020;46:8468. https://doi.org/10.1007/s00134-020-05991-x

PMid:32125452

56. Patruno C, Nisticò SP, Fabbrocini G, Napolitano M. COVID-19, quarantine, and atopic dermatitis. Med Hypotheses. 2020;143(1):109852. https://doi.org/10.1016/j. mehy.2020.109852

PMid:32447099

57. Wollenberg A, Flohr C, Simon D, Cork MJ, Thyssen JP, Bieber T, et al. European Task Force on Atopic Dermatitis statement on severe acute respiratory syndrome coronavirus 2 (SARSCov-2) infection and atopic dermatitis. J Eur Acad Dermatology Venereol. 2020;34(6):e241-2. https://doi.org/10.1111/jdv.16411 PMid:32223003

58. Napolitano M, Patruno C, Ruggiero A, Nocerino M, Fabbrocini G Safety of dupilumab in atopic patients during COVID-19 outbreak. J Dermatolog Treat. 2020;1:1-2. https://doi.org/10.10 80/09546634.2020.1771257

59. Georgakopoulos JR, Yeung J. Patient-driven discontinuation of dupilumab during the COVID-19 pandemic in two academic hospital clinics at the University of Toronto. J Cutan Med Surg 2020;1:1-2. https://doi.org/10.1177/1203475420930223

60. Lafaille JJ. The role of helper $T$ cell subsets in autoimmune diseases. Cytokine Growth Factor Rev. 1998;9(2):139-51. https://doi.org/10.1016/s1359-6101(98)00009-4 PMid:9754708

61. Hamilton JD, Suárez-Fariñas M, Dhingra N, Cardinale I, Li X Kostic A, et al. Dupilumab improves the molecular signature in skin of patients with moderate-to-severe atopic dermatitis. J Allergy Clin Immunol. 2014;134(6):1293-300. https://doi. org/10.1016/j.jaci.2014.10.013 PMid:25482871

62. Patruno C, Stingeni L, Fabbrocini G, Hansel K, Napolitano M. Dupilumab and COVID-19: What should we expect? Dermatol Ther. 2020;33(4):13502. https://doi.org/10.1111/dth.13502

63. Nicolson KS, Streeter HB, Verhagen J, Sabatos-peyton CA, Morgan DJ, Wraith DC. Negative feedback control of the autoimmune response through antigen-induced differentiation of IL-10-secreting Th1 cells. J Exp Med. 2009;206(8):1755-67. https://doi.org/10.1084/jem.20082118

PMid:19635862

64. Fowler DH. Th1/Th2 and Tc1/Tc2 cells: Experimental models and clinical translation. J Allergy Clin Immunol. 2001;107(2):337-44 


\section{Appendix}

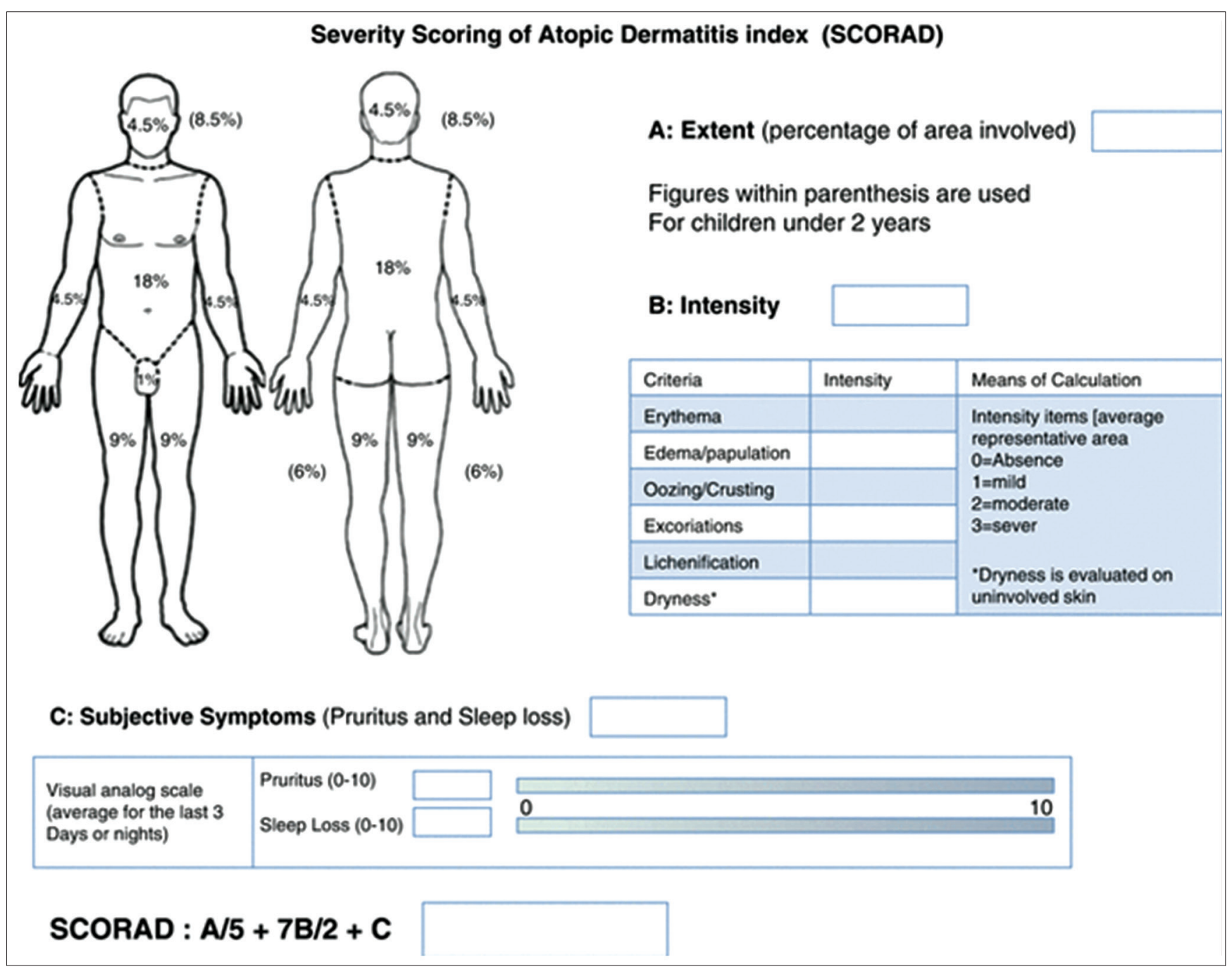

Appendix 1: SCORAD. Adapted from. Honari G. (2017) Clinical Scoring of Atopic Dermatitis. In: Humbert P., Fanian F., Maibach H., Agache P. (eds) Agache's Measuring the Skin. Springer, Cham. https://doi.org/10.1007/978-3-319-32383-1_94 